\title{
Antibacterial Activity of Seed and Leaf Extract of Carica Papaya var. Pusa dwarf Linn
}

\author{
Jyotsna Kiran Peter*, Yashab Kumar, Priyanka Pandey and Harison Masih \\ Department of Microbiology and Fermentation Technology, JSBB, SHIATS- Deemed to be University, Naini, \\ UP, India 211008 .
}

\begin{abstract}
The study dealt with the antibacterial activity of aqueous, chloroform extract of leaves and aqueous, methanolic extract of seeds of Carica papaya var. pusa dwarf through agar well diffusion assay against Staphylococcus aureus, Pseudomonas aeruginosa, E. coli and Salmonella typhi. It was revealed that the aqueous as well as the methanolic extract of seeds were effective to inhibit the bacterial pathogens while in case of chloroform extract of Carica papaya leaves did not show any inhibition against the bacteria and the aqueous leaf extract was potent to inhibit them.
\end{abstract}

Key words: Carica papaya var. pusa dwarf, antibacterial activity, seed extract, leaf extract, bacterial pathogens

\section{Introduction}

Carica papaya belongs to the family of Caricaceae, and several species of Caricaceae have been used as remedy against a variety of diseases (Alabi et al., 2012). Carica papaya is a neutraceutical plant having a wide range of pharmacological activities. The whole plant has its own medicinal value. Papaya is a powerhouse of nutrients and is available throughout the year. It is a rich source of threes powerful antioxidant vitamin $\mathrm{C}$, vitamin $\mathrm{A}$ and vitamin $\mathrm{E}$; the minerals, magnesium and potassium; the B vitamin pantothenic acid and folate and fiber (Aravind et al., 2013).

The black seeds of the papaya are edible and have a sharp, spicy taste. They are sometimes ground and used as a substitute for black pepper. Dried papaya seeds actually look quite similar to peppercorns and can be used in just the same way. Grinding a couple over a meal, especially protein rich meals, is a simple way to add extra enzymes to your diet and improve your digestive health. The papaya seeds are very pungent and peppery, making them almost unpalatable. However the seeds seem to have more potent medicinal values than the flesh. Papaya seeds have antibacterial properties and are effective against E. coli, Salmonella and Staphylococcus infections. Papaya seeds may protect the kidneys from toxin induced kidney failure. Papaya can eliminate intestinal parasites. Cure for piles and typhoid and anti-helminthic and anti-amoebic properties (Aravind et al., 2013). The seed of papaya has antimicrobial activity against Trichomonas vaginali strophozoites. It could also be used in urinogenital disorder like trichomoniasis with care to avoid toxicity. The seeds, irrespective of its fruit maturity stages have bacteriostatic activity on gram positive and negative organisms which could be useful in treating chronic skin ulcer. However, little information exits on the antimicrobial property of C. papaya dried and fresh leaves (Alabi et al., 2012). Recently, antifertility (Lohia et al., 1999) antihelminthic,(Satrija et al., 1995) and anti-inflammatory activity (Oladunmoye, and Osho, 2007) have been reported. CP seeds possess moisture, proteins, fatty acids, and phospholipids, such as phosphotidylcholine and cardiolipin. Other compounds present in seeds are carpaine, benzyl isothiocynate, benzyl glucosinolate, beta-sitosterol,caricin, enzyme myrosin. The well-studied proteinases from papaya are papain, chymopapain, caricain, and glycylendopeptidase. Papain occurs in all parts of the tree except the root (Anonymous, 1992). Fruit and seed extracts have antibacterial activity against Staphylococcus aureus, Bacillus cereus, Escherischiacoli, and Pseudomonas aeuroginosa (Tang et al., 1972; Emeruwa, 1982). The juice is used for curing warts, cancer, and tumors. Leaves have beenpoulticed into nervous pains, elephantoid growths (Asolkaret al., 1992). The antihyperglycemic effect of unripe mature fruits and seeds of CP have also been reported (Olagunja, et al 1995; Adeneye and Olagunja, 2009).

Papaya leaves are made into tea as a treatment for malaria. Antimalarial and antiplasmodial activity has been noted in some preparations of the plant, the leaves of the papaya plants contain chemical compounds of karpain, Substance which kills microorganisms that often interfere with the digestive function (Udohet al., 2005). Papaya leaf extracts have phenolic compounds, such as protocatechuic acid, p-coumaric acid, 5, 7dimethoxycoumarin, caffeic acid, kaempferol, quercetin, chlorogenic acid (Romasi et al., 2011).Antimicrobials of plant origin effective in the treatment of infectious diseases and simultaneously mitigating many of the side effects often associated with synthetic antimicrobial agents have been discovered. Medical uses of plants range from the administration of the roots, barks, stems, leaves and seeds to the use of extracts and decoction from the plants (Iwuet al., 1999). 


\section{Materials And Methods}

Preparation of methanolic and hot aqueous seed extract

Seeds of Carica papaya var. pusa dwarf Linn were collected from Agriculture Research Farm, SHIATS, Naini, UP. The seed extract was prepared as described in WHO, 1983 with slight modification through hot extraction method. Air dried ripened papaya seeds were powdered using mortar and pestle. For aqueous extract, $5 \mathrm{~g}$ of dried and powdered seeds were mixed in $100 \mathrm{ml}$ distilled water while for solvent extract preparation $70 \%$ methanol was used. The contents were kept in water bath for $1 \mathrm{~h}$ at $40^{\circ} \mathrm{C}$. After cooling both extracts were filtered successively through ordinary cheese cloth and Whatmann filter paper. The residue was then resuspended in same amount of distilled water and 70\% methanol and the process was repeated 3-4 times. The extracts were then air dried using a water bath at $40^{\circ} \mathrm{C}$ and dissolved in DMSO to form different concentrations of viz. 25, 50, 75 and 100\% aqueous and methanolic extracts respectively. The hot water seed extract was prepared according to the as described by Oyagade et al., 1999. The hot water extraction was done at $80^{\circ} \mathrm{C}$ in a water bath for $1 / 2$ hours. The extracts were then decanted and filtered through a Whatman filter paper. The filtered extract was then sterilized using a membrane filter and evaporated to dryness at $45^{\circ} \mathrm{C}$.

\section{Preparation of leaf extract}

Healthy, fresh young leaves of Carica papaya var. pusa dwarf Linn were collected from Agriculture research farm, SHIATS, Naini, UP. The leaf extract was prepared as described by Suresh et al., 2008 with slight modification. Leaves were rinsed under tap water and then by double distilled water then dried at room temperature for 15 days. $20 \mathrm{~g}$ dried leaves were grounded to powder using a mixer grinder. $20 \mathrm{~g}$ dried leaves powder was soaked in chloroform for extraction in a rotary shaker for 3-5 days. The extract was then filtered through cheesecloth and the extract was reduced to $10 \%$ of the original volume using a water bath at $40^{\circ} \mathrm{C}$ finally dried as powder. The same process was used for aqueous extract preparation.

\section{Antibacterial activity of aqueous and $70 \%$ methanolic extract of Carica papaya seeds}

The antibacterial activity of aqueous and $70 \%$ methanolic extracts of Carica papaya seeds was examined using agar well diffusion assay as described by. Known concentrations of aqueous and 70\% methanolic extracts of Carica papaya seeds i.e. 25, 50, 75, $100 \mathrm{mg} / \mathrm{ml}$ DMSO were prepared. To the solidified Nutrient agar medium (composition in g/L: peptone:5; sodium chloride:5; beef extract:3; agar agar:17; pH: 7.2) $5 \mathrm{~mm}$ wells were cut. An uninoculated plate served as media control and test bacteria swab inoculated was used as a organism control. A plate swab inoculated with test bacteria with a well filled with DMSO was used as treatment control. To the test plates an aliquot of each concentration of aqueous and $70 \%$ methanolic extracts of Carica papaya seeds was filled after swab inoculation of test bacteria viz. Staphylococcus aureus and gram negative bacteria i. e. Pseudomonas aeruginosa, E. coli and Salmonella typhi. All the plates were allowed to incubate at $37^{\circ} \mathrm{C}$ for $24-48 \mathrm{~h}$ in bacteriological incubator. After incubation the clear zone around the well was measured in $\mathrm{mm}$ scale defined as zone of inhibition of the test bacteria.

\section{Results And Discussion}

Table 1: Antibacterial activity of $70 \%$ methanolic extract of Carica papaya seeds on bacterial pathogens

Sample extract $\begin{array}{r}\text { Concentration } \\ (\mathrm{mg} / \mathrm{mlDMSO})\end{array}$

Zone of Inhibition (mm)

\begin{tabular}{cccccc}
\hline $\begin{array}{cccc}70 \% \text { methanolic } \\
\text { extract of seeds }\end{array}$ & S. aureus & $\begin{array}{c}\text { Pseudomonas } \\
\text { aeruginosa }\end{array}$ & E. coli & S typhi \\
of Carica & 25 & 3.2 & 3.2 & 3.0 & 0.00 \\
papaya & 50 & 4.7 & 4.5 & 4.2 & 0.00 \\
& 75 & 7.3 & 7.1 & 6.1 & 0.00 \\
& 100 & 10.0 & 8.2 & 7.4 & 3.0 \\
\hline
\end{tabular}

Table 2: Antibacterial activity of aqueous extract of Carica papaya seeds on bacterial pathogens

\begin{tabular}{cc} 
Sample extract & $\begin{array}{c}\text { Concentration } \\
(\mathrm{mg} / \mathrm{ml} \text { DMSO })\end{array}$ \\
\hline
\end{tabular}

Zone of Inhibition (mm)

\begin{tabular}{|c|c|c|c|c|c|}
\hline $\begin{array}{l}\text { aqueous extract of } \\
\text { seeds of Carica }\end{array}$ & & S. aureus & $\begin{array}{c}\text { Pseudomonas } \\
\text { aeruginosa }\end{array}$ & E. coli & S typhi \\
\hline \multirow[t]{4}{*}{ papaya } & 25 & 3.0 & 2.5 & 2.5 & 0.00 \\
\hline & 50 & 4.2 & 4.1 & 3.9 & 0.00 \\
\hline & 75 & 7.1 & 6.3 & 5.5 & 0.00 \\
\hline & 100 & 9.5 & 7.5 & 7.0 & 2.5 \\
\hline
\end{tabular}


Table 3: Antibacterial activity of chloroform extract of Carica papaya leaves on bacterial pathogens

Concentration

(mg/mlDMSO)

Zone of Inhibition (mm)

Chloroform extract

of leaves of Carica

papaya

\begin{tabular}{ccccc}
\cline { 2 - 4 } & S. aureus & $\begin{array}{c}\text { Pseudomonas } \\
\text { aeruginosa }\end{array}$ & E. coli & S typhi \\
25 & 2.5 & 2.2 & 2.4 & 2.7 \\
50 & 3.8 & 4.0 & 3.7 & 4.3 \\
75 & 4.8 & 5.9 & 4.8 & 6.7 \\
100 & 8.4 & 7.8 & 6.9 & 8.8 \\
\hline
\end{tabular}

Table 4: Antibacterial activity of aqueous extract of Carica papaya leaves on bacterial pathogens

\begin{tabular}{|c|c|c|c|c|c|}
\hline $\begin{array}{c}\text { Sample extract } \\
\begin{array}{c}\text { Aqueous extract of } \\
\text { leaves of Carica } \\
\text { papava }\end{array}\end{array}$ & $\begin{array}{c}\text { Concentration } \\
\text { (mg/ml DMSO) }\end{array}$ & \multicolumn{4}{|c|}{ Zone of Inhibition (mm) } \\
\hline $\begin{array}{c}\text { Aqueous extract of } \\
\text { leaves of Carica } \\
\text { papaya }\end{array}$ & $\begin{array}{c}25 \\
50 \\
75 \\
100\end{array}$ & $\begin{array}{l}\text { S. aureus } \\
\\
3.2 \\
5.1 \\
7.1 \\
9.8\end{array}$ & $\begin{array}{c}\text { Pseudomonas } \\
\text { aeruginosa } \\
3.0 \\
4.8 \\
5.4 \\
8.5\end{array}$ & $\begin{array}{c}\text { E. coli } \\
\\
3.0 \\
3.5 \\
4.9 \\
6.2\end{array}$ & $\begin{array}{c}0.00 \\
0.00 \\
0.00 \\
2.5\end{array}$ \\
\hline
\end{tabular}

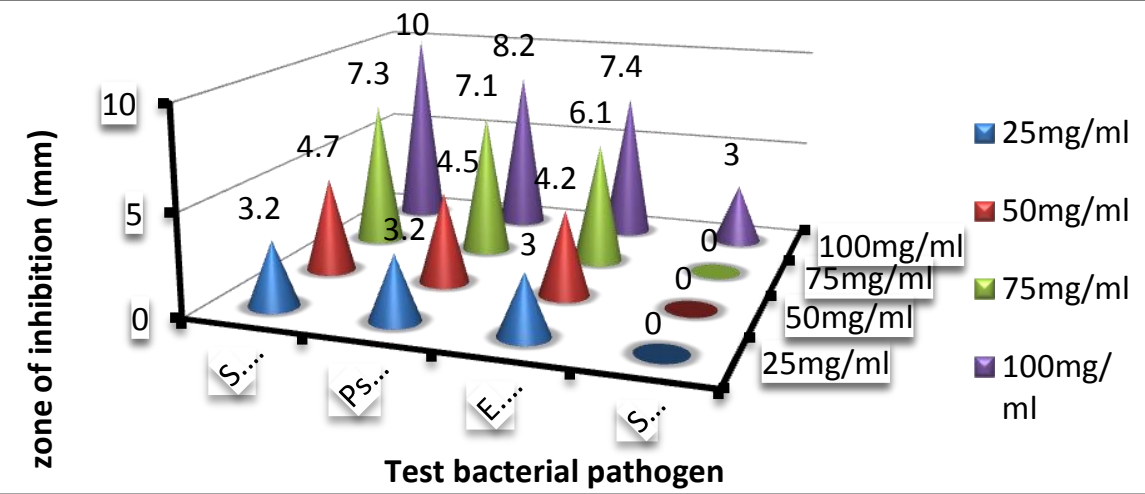

Fig 1: Antibacterial activity of $70 \%$ methanolic extract of seeds of Carica papaya leaves on bacterial pathogens

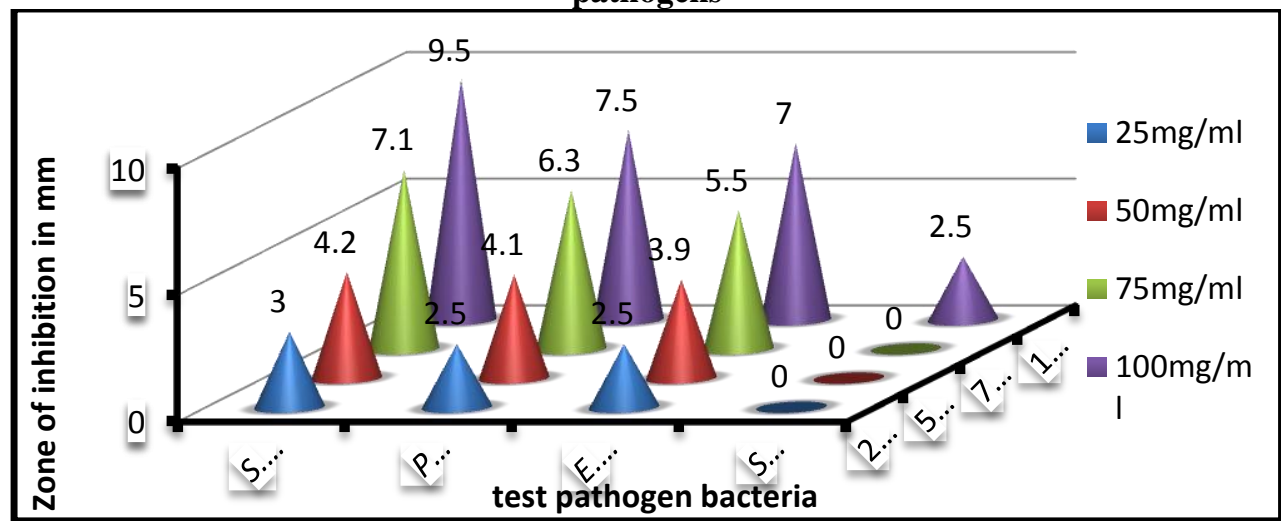

Fig 2: Antibacterial activity of aqueous extract of seeds of Carica papaya leaves on bacterial pathogens 


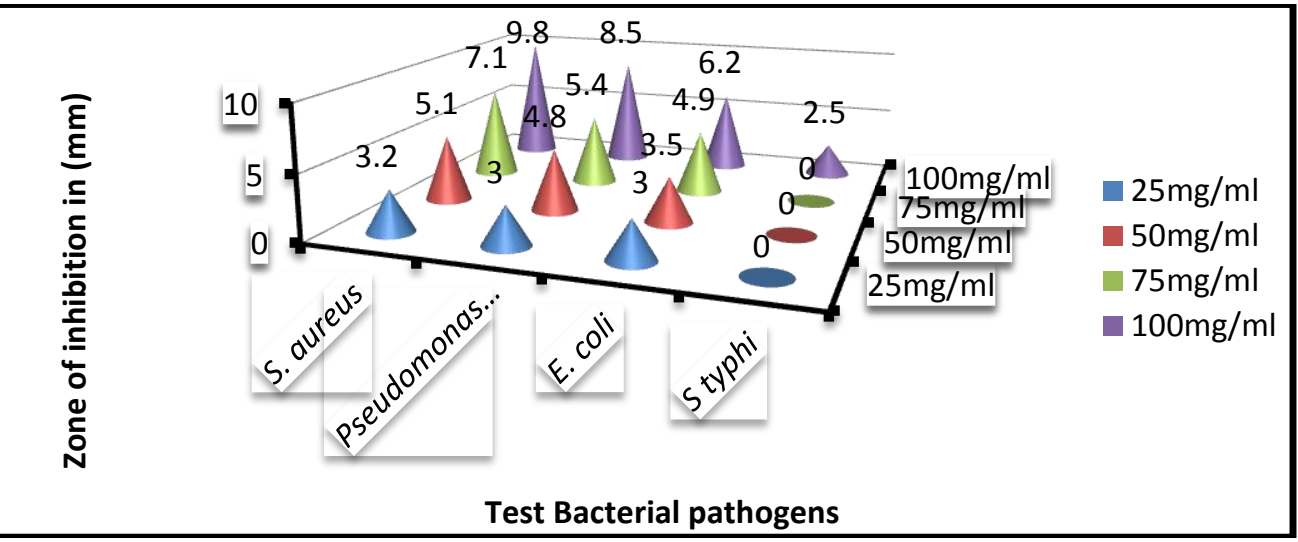

Fig 3: Antibacterial activity of chloroform extract of Carica papaya leaves on bacterial pathogens

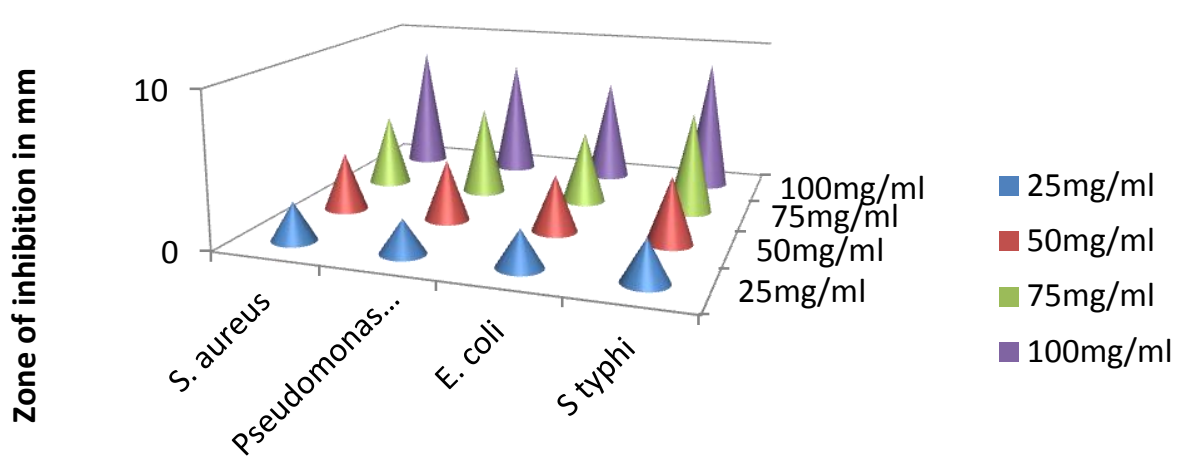

Test bacterial pathogen

Fig 4: Antibacterial activity of aqueous extract of Carica papaya leaves on bacterial pathogens

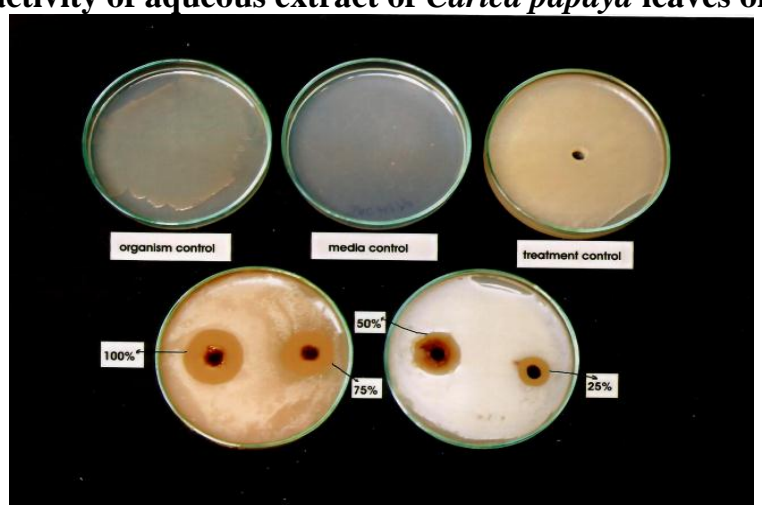

Plate1: Antibacterial activity of aqueous seed extract of Carica papaya var. pusa dwarf on E. coli

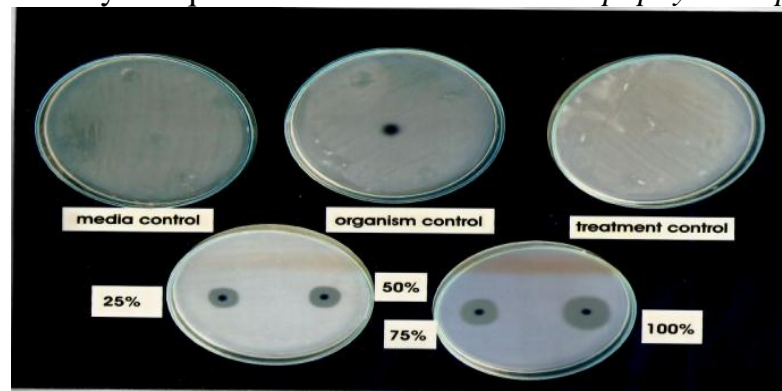

Plate 2: Antibacterial activity of aqueous leaf extract of Carica papaya var. pusa dwarf on E. coli 


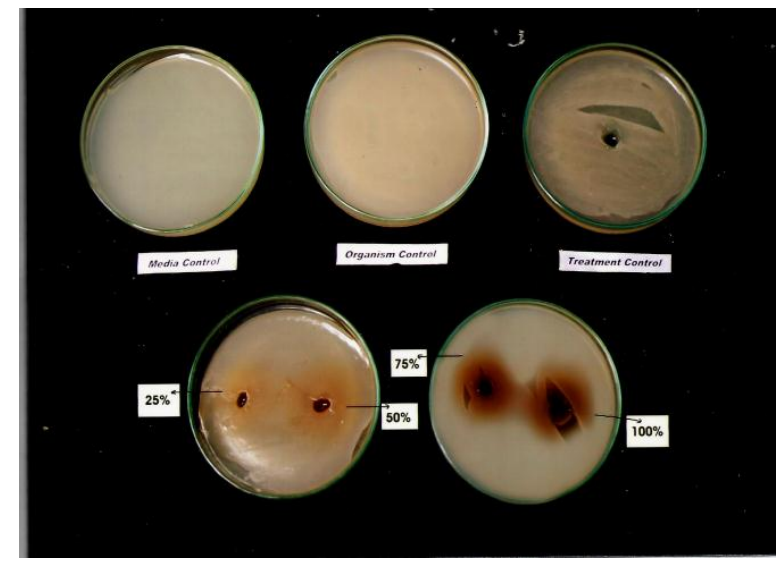

Plate: 3 Antibacterial activity of chloroform leaf extract of Carica papaya var. pusa dwarf on Pseudomonas auruginosa

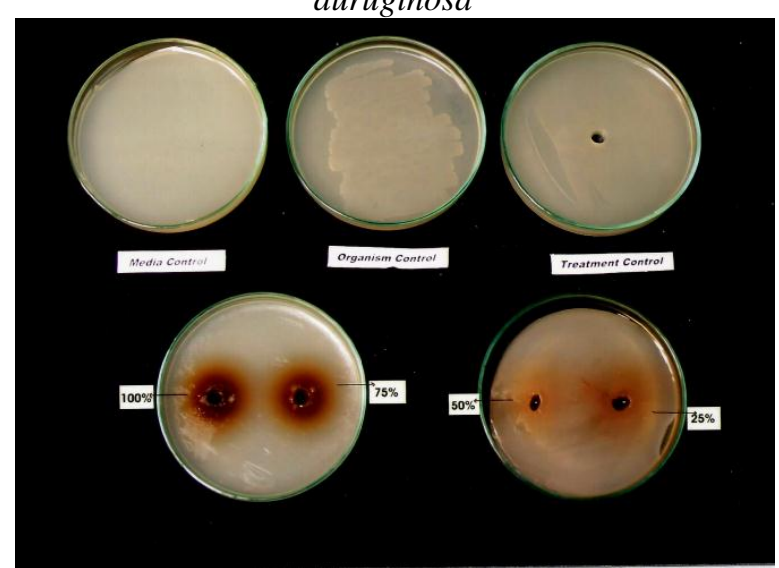

Plate: 4 Antibacterial activity of chloroform leaf extract of Carica papaya var. pusa dwarf on S. aureus

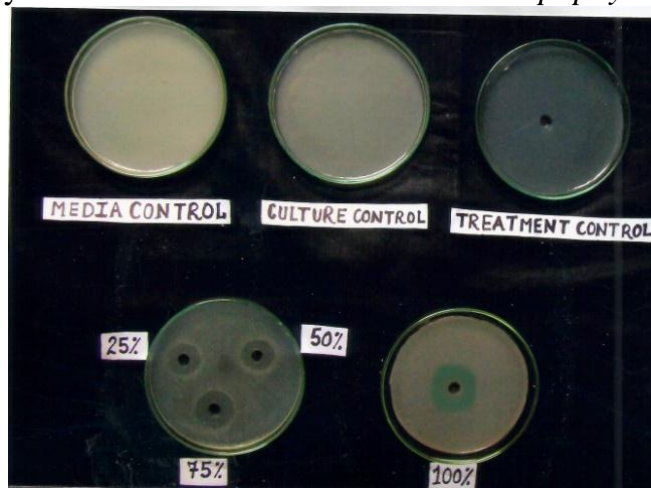

Plate: 5 Antibacterial activity of aqueous leaf extract of Carica papaya var. pusa dwarf on Pseudomonas auruginosa

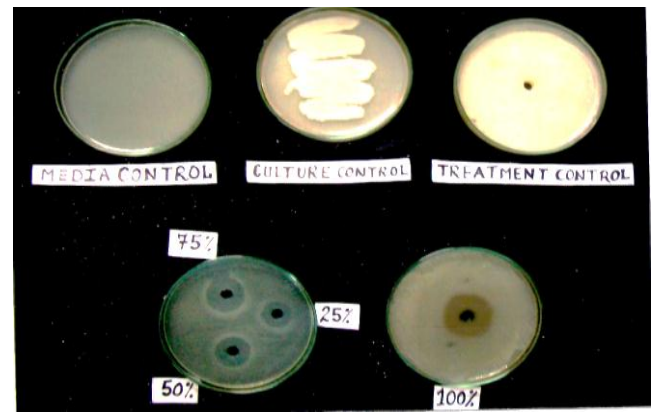

Plate: 6 Antibacterial activity of aqueous seed extract of Carica papaya var. pusa dwarf on Salmonella typhi 

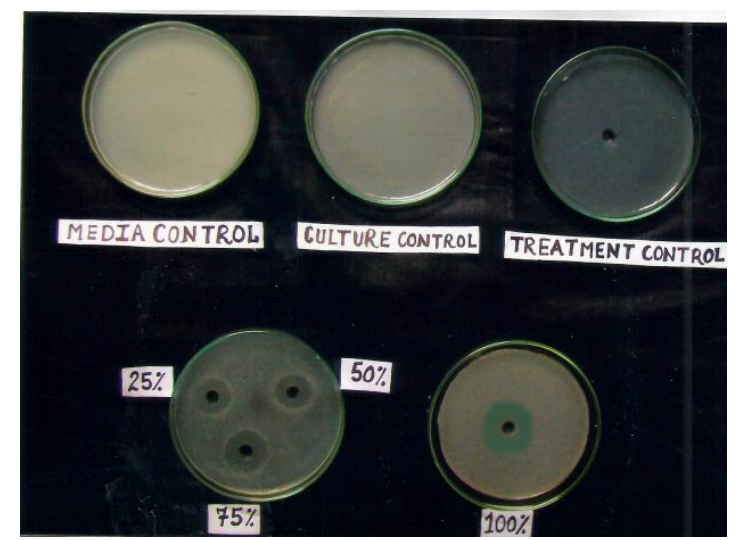

Plate: 7 Antibacterial activity of aqueous seed extract of Carica papaya var. pusa dwarf on Pseudomonas auruginosa

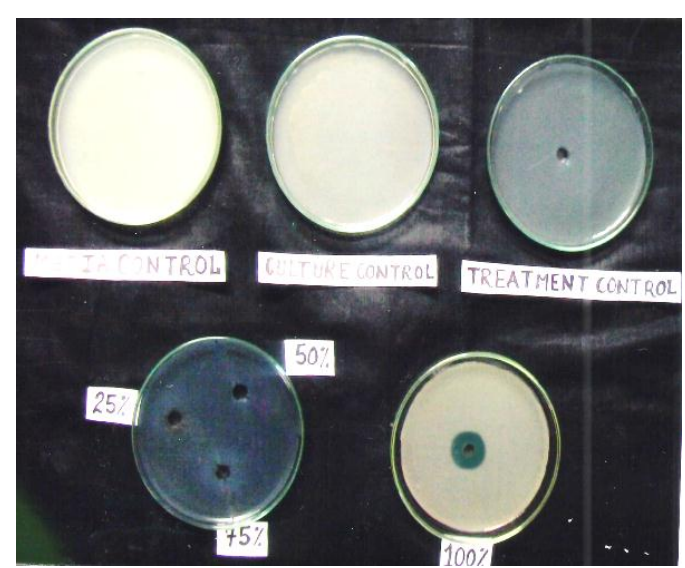

Plate: 8 Antibacterial activity of methanolic seed extract of Carica papaya var. pusa dwarf on S. aureus

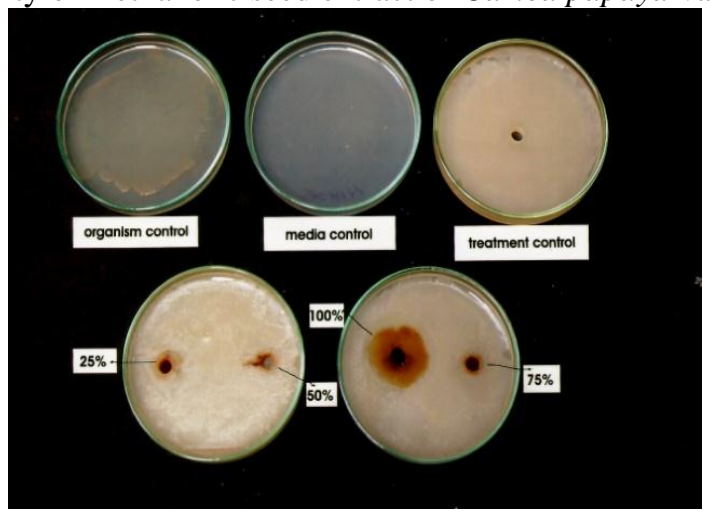

Plate: 9 Antibacterial activity of aqueous leaf extract of Carica papaya var. pusa dwarf on Salmonella typhi
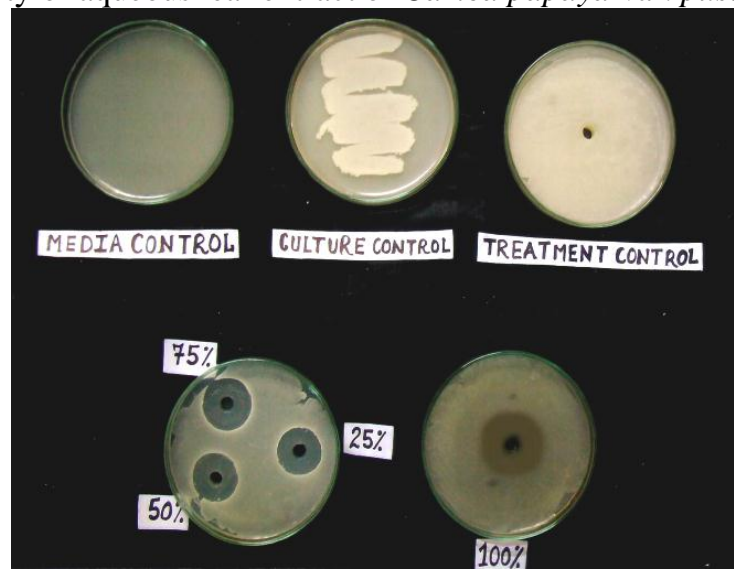

Plate: 10 Antibacterial activity of aqueous leaf extract of Carica papaya var. pusa dwarf on S. aureus 


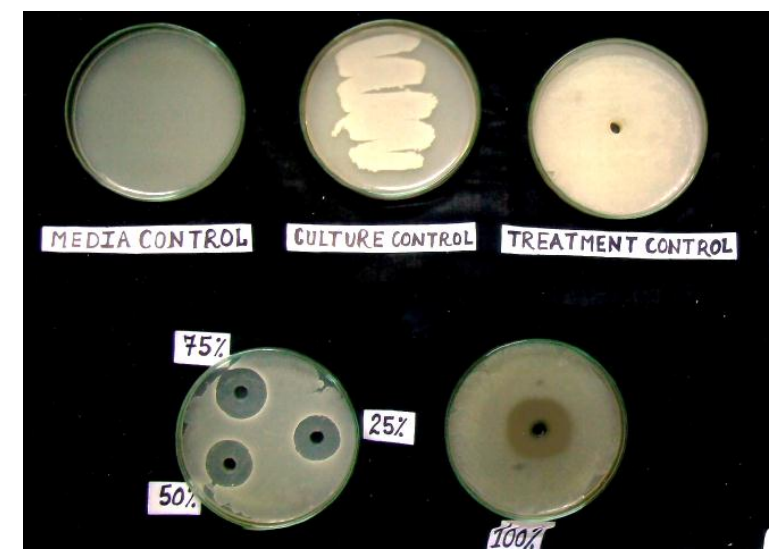

Plate: 11 Antibacterial activity of aqueous seed extract of Carica papaya var. pusa dwarf on S. aureus

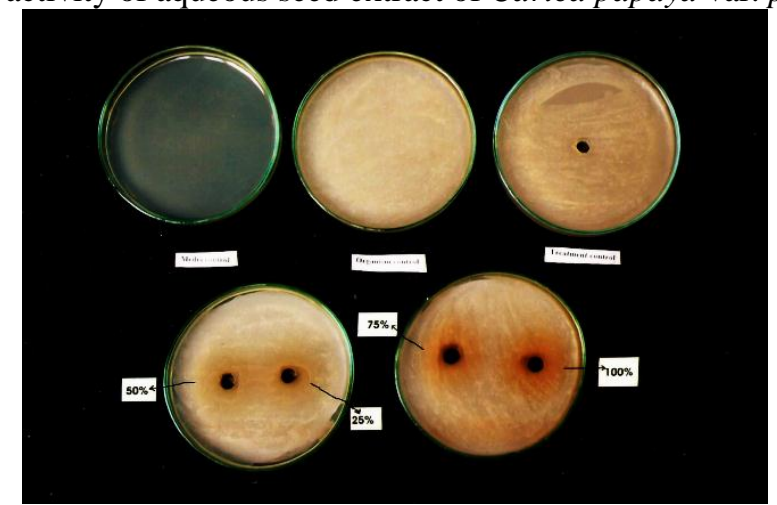

Plate: 12 Antibacterial activity of chloroform leaf extract of Carica papaya var. pusa dwarf on Salmonella typhi

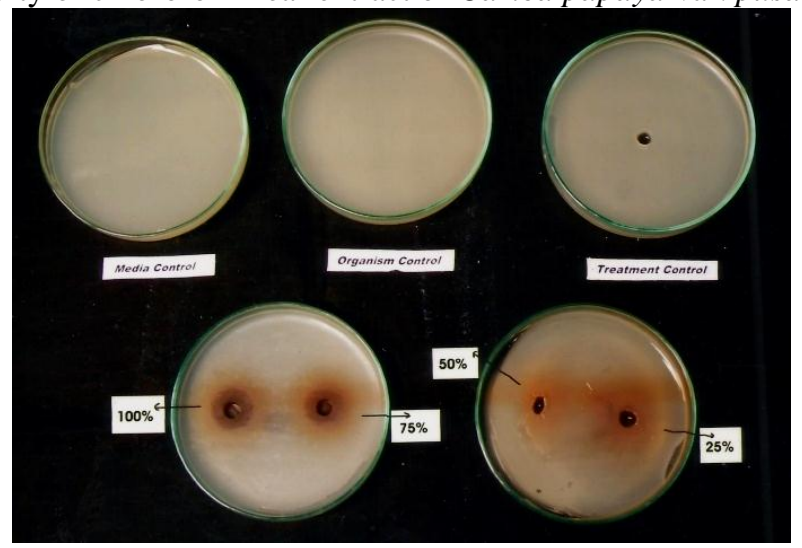

Plate: 13 Antibacterial activity of chloroform leaf extract of Carica papaya var. pusa dwarf on E. coli
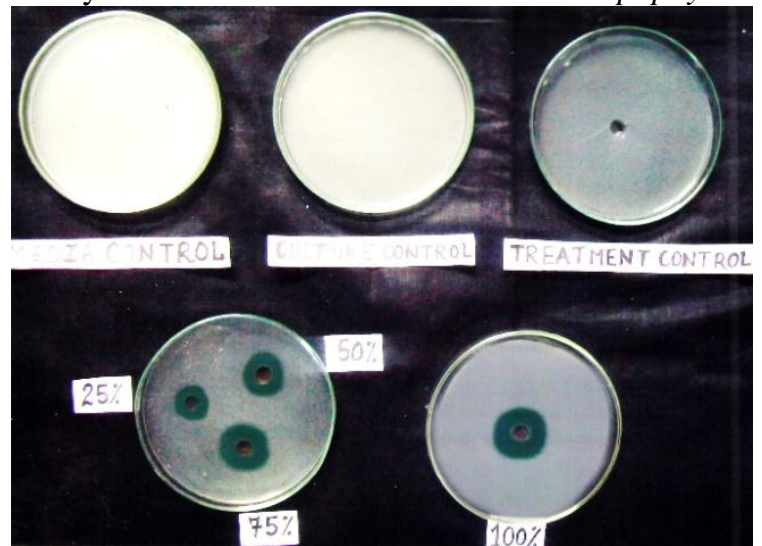

Plate: 14 Antibacterial activity of methanolic seed extract of Carica papaya var. pusa dwarf on Pseudomonas auruginos 


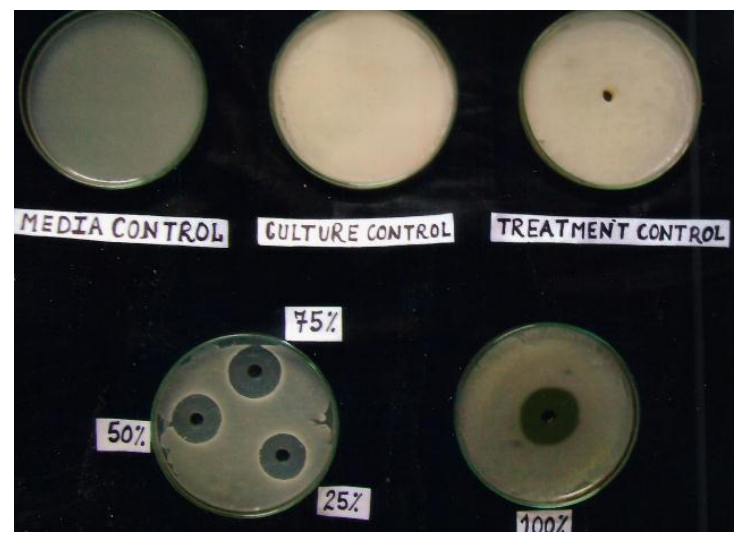

Plate: 15 Antibacterial activity of methanolic seed extract of Carica papaya var. pusa dwarf on E. coli

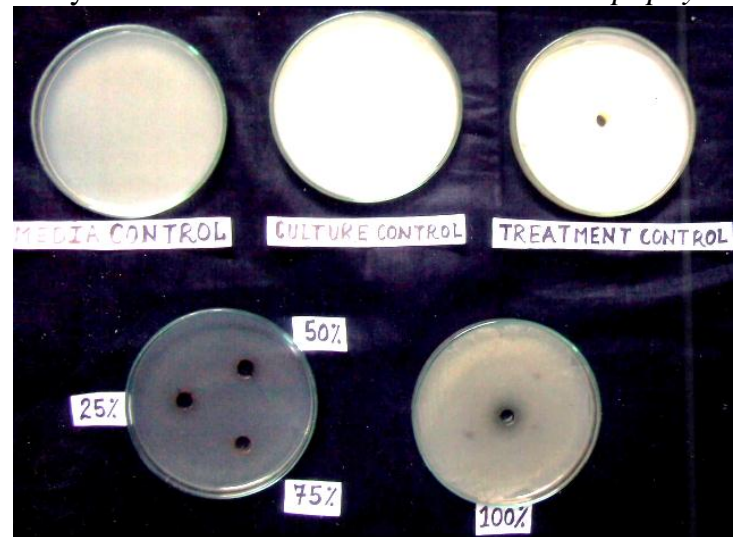

Plate: 16 Antibacterial activity of methanolic seed extract of Carica papaya var. pusa dwarf on Salmonella typhi

Aqueous extract of Carica papaya seeds showed increasing zone of inhibition of S. aureus, P. aeruginosa and $E$. coli with increasing seed extract concentration as $25,50,75$ and $100 \mathrm{mg} / \mathrm{ml}$ while the extract concentration of 25,50 , and $75 \mathrm{mg} / \mathrm{ml}$ were unable to show zone of inhibition against $S$. typhi and the pathogen was inhibited at $100 \mathrm{mg} / \mathrm{ml}$ concentration of the extract with a zone of inhibition of $2.5 \mathrm{~mm}$ (Table: 1 ; Fig: 1 ).

$70 \%$ methanolic extract of Carica papaya seeds inhibited S. aureus, P. aeruginosa and E. coli with increasing seed extract concentration as $25,50,75$ and $100 \mathrm{mg} / \mathrm{ml}$ while the extract concentration of 25,50 , and $75 \mathrm{mg} / \mathrm{ml}$ were unable to show zone of inhibition against $S$. typhi and the pathogen was inhibited at $100 \mathrm{mg} / \mathrm{ml}$ concentration of the extract with a zone of inhibition of $3.0 \mathrm{~mm}$. Among the four concentrations $100 \mathrm{mg} / \mathrm{ml}$ of extract concentration of seeds of Carica papaya had highest zone of inhibition against all pathogenic bacteria tested (Table: 2; Fig: 2).

Aqueous, n-hexane and ethanol extract of Carica papaya leaves was investigated by Chandra et al., 2011 for antibacterial activity of $S$. aureus, B. subtilis, E. coli, and Pseudomonas auruginasa and it was observed that the three extracts were able to inhibit all the bacteria tested. Among the three extract $\mathrm{n}$-hexane and ethanol had highest inhibition of $S$. aureus 17.33 and $15.67(30 \mathrm{mg} / \mathrm{disc})$ while aqueous extract had inhibition of $9(30 \mathrm{mg} / \mathrm{disc})$ also in case of B. subtilis, E. coli, and Pseudomonas auruginasa. Mangalanayaki and Nirosha, 2013 examined the antibacterial activity of the leaves of the Carica papaya using solvents ethanol and ethyl acetate against Staphylococcus aureus, Streptococcus pneumonia, Bacillus cereus, Salmonella typhi, Escherichia coli and Pseudomonas aeruginosa by well diffusion method. The extract demonstrated higher activities against all the Gram negative bacteria than Gram positive bacteria tested, with the highest activity (16 $\mathrm{mm}$ zone of inhibition) demonstrated against Salmonella typhi. The ethanolic extract leaves and roots moderately to kill all the bacterial pathogens than aqueous extract of leaves and root. Ogunjobi and Ogunjobi (2011) through cold extraction precipitation on eight bacterial strains Staphylococcus aureus; Salmonella typhi B; Shigella dysenteria; Pseudomonas aeruginosa; Serratia marcescens; Pseudomonas fluorescens; Proteus vulgaris; and Bacillus subtillis. Romasi et al., 2011 studied the ethanol, ethyl acetate, and hexane extract of papaya leaf against Bacillus stearothermophilus, Listeria monocytogenes, Pseudomonas sp., and Escherichia coli by agar diffusion method. The results of the study conducted by Hema et al., 2013 showed that the propanolic extracts of Carica papaya were more effective than the ethanol extracts demonstrated the highest activity. Among the Grampositive and Gram-negative bacteria tested against the leaf extract of $C$. papaya, the Gram-negative bacteria were more susceptible especially Proteus vulgaris to the extracts. This result, however, is at disparity with an earlier report indicating that plant extracts are more active against Gram-positive bacteria than Gram-negative 
bacteria while that of the leaf extract of $C$. papaya was next to the most sensitivity with the Gram-negative bacteria especially Proteus mirabilis (Jigna and Sumitra, 2006). The fact that the extracts were active against both Gram negative and Gram positive bacteria tested may indicate a broad spectrum of activity and the phytochemical analysis revealed the presence many phyto constituents. This observation is very significant because of the possibility of developing therapeutic substances that will be active against multidrug-resistant organisms. Zakira et al., 2006 analyzed the antimicrobial activity of Carica papaya flowers against bacterial pathogens. Romasi et al., 2011 reported that the extracts of papaya leaves could inhibit the growth of Rhizopus stolonifer. Antibacterial activity of Carica papaya leaf extracts on pathogenic bacteria was observed in this study. Papaya leaves were extracted by using maceration method and three kinds of solvents: ethanol, ethyl acetate, and hexane. Papaya leaf extracts were tested against Bacillus stearothermophilus, Listeria monocytogenes, Pseudomonas sp., and Escherichia coli by agar diffusion method. This research indicated that papaya leaves have potential natural antibacterial compounds. Sherwani et al., 2013; Omojasola and Awe, 2004 also examined the leaf extract of Carica papaya against plant and human pathogenic bacteria.

\section{Acknowledgements}

The authors offer gratuitous thanks to Hon'ble Vice Chancellor, Most Rev. Prof. R.B. Lal, SHIATS, Naini, Uttar Pradesh, India for provision of research conductance. Heartfelt thanks to HoD, Department of Microbiology and Fermentation Technology, JSBB, SHIATS, Allahabad for the kind cooperation towards the research.

\section{References}

[1]. Adeneye AA, Olagunja JA. Preliminary hypoglycemic andhypolipidemic activities of aqueous seed extract of Carica papaya Linn in Wistar rats. Biol Med. 2009; 1:1-10.

[2]. Alabi, OA., Haruna, MT., Anokwuru, CP., Jegede, T., Abia, H., Okegbe, V. and Esan, E. 2012.Comparative studies on antimicrobial properties of extracts of fresh and dried leaves of Carica papaya (L) on clinical bacterial and fungal isolates. Pelagia Research Library. 3 (5):3107-3114.

[3]. Anonymous.The Wealth of India.Raw materials.Ca-Ci, Publication and Information Directorate, CSIR, New Delhi, India.1992. p. 287-93.

[4]. Aravind. G, Debjit B, Duraivel. S, Harish. G. 2013. Traditional and Medicinal Uses of Carica papaya. Journal of Medicinal Plants Studies. 1(1): 7-15.

[5]. Asolkar LV, Kakkar KK, Chakre OJ. Glossary of Indian Medicinal Plants with active principles. Part 1 (A-K).Publications by Information Directorate, CSIR New Delhi. 1992. p. 171-3.

[6]. Chandra, G., Ghosh, A., Chatterjee, SK., Bhattacharjee, I. 2011. Antibacterial activities of some plant extracts used in Indian traditional folk medicine. Asian Pacific Journal of Tropical Biomedicine.S165-S169.

[7]. Emeruwa AC. Antibacterial substance from Carica papayafruit extract. J Nat Prod.1982; 45:123-7.

[8]. Hema, T.A., Arya, A.S., Subha, S., John, C.R.K. and Divya, P.V. 2013. Antimicrobial activity of five south Indian medicinal plants against clinical pathogens. International Journal of Pharma and Bio Sciences. 4(1): $70-80$.

[9]. Iwu, M.W. Duncan, A.R. Okunji, C.O. New antimicrobials of plant origin. (Janick, J. (ed.), Perspectives on New Crops and New uses). ASHS Press, Alexandria, 1999

[10]. Jigna $\mathrm{P}$ and Sumitra C.(2006).In vitro antimicrobial activity of medicinal plants. Afr. J. Biomed, 9(2):89-93.

[11]. Lohiya NK, Mishra PK, Pathak N, Munivannan B, Jain SC. Reversible azospermia by oral administration of the benzene chromatographic fraction of the chloroform extracts of the seeds of Carica papaya in rabbits. Adv Contracept 1999; 15:141-61.

[12]. Mangalanayaki, R. and Nirosha, N. 2013. Antibacterial Activity of Leaves and Stem Extract of Carica papaya L. International Journal of Advances in Pharmacy, Biology and Chemistry. 2(3): 473-476.

[13]. Ogunjobi, AA. and Ogunjobi, T E. (2011). Comparative study of antibacterial activities of Garcinia kola and Carica papaya. African Journal of Biomedical Research.14 (2): 147- 152.

[14]. Oladunmoye MK, Osho IB. Anti-inflammatory activity ofethanolic leaf extract from Carica papaya in rats, orogastricallydosed with Salmonella typhiand Staphylococcus aureus.

[15]. Olagunja JA, Ogunlana CO, Gbile Z. Preliminary studieson the hypoglycemic activity of ethanolic extract of unripemature fruits of Carica papaya. Nig J BiochemMolBiol1995; 10:21-3.

[16]. Omojasola, P. F. and Awe, S. 2004. The Antibacterial activity of the leaf extract of Anacardiumoccidentaleand Gossyptumhirsutumagainst some selected microorganisms. Bioscience Research Communication 16 (1). Plant Sci. 2007; 2:447-445.

[17]. Romasi, E F., Karina, J. and Parhusip, A J N. 2011. Antibacterial activity of papaya leaf extracts against pathogenic bacteria.Makara, Teknologi. 15(2): 173-177.

[18]. Satrija F, Nansen P, Murtini S, He S. Anthelmintic activityof papaya latex against patent Heligmosomoides polygyrus infections in mice. J Ethnopharm 1995; 3:161-4.

[19]. Sherwani, S.K., Bokhan, T.Z., Nazim, K., Gilani, S.A. and Kazim, S.U. 2013.Qualitative phytochemical screening and antifungal activity against human and plant pathogenic bacteria. International Research Journal of Pharmacy. 4(7): 1-8.

[20]. Tang CS, Syed MM, Hamilton RA. Benzyl isothiocyanate in the Caricaceae. Phytochemistry. 1972; 11:2531-3.

[21]. Udoh P, Essien I, Udoh F. 2005. Effect of Carica papaya (paw paw) seeds extract on the morphology of pituitary-gonadal axis of male Wistar rats. Phytother Res.19:1065-8.

[22]. Zakaria, Z. A., Jais, A.M.M., Sulaiman, M.R., Isa, M.S.P.P. and Riffin, S. 2006. The in vitro antibacterial activity of Carica papaya flowers and Mangifera indica leaves. J. of Pharmacology and Toxicology. 1(3): 278-283. 